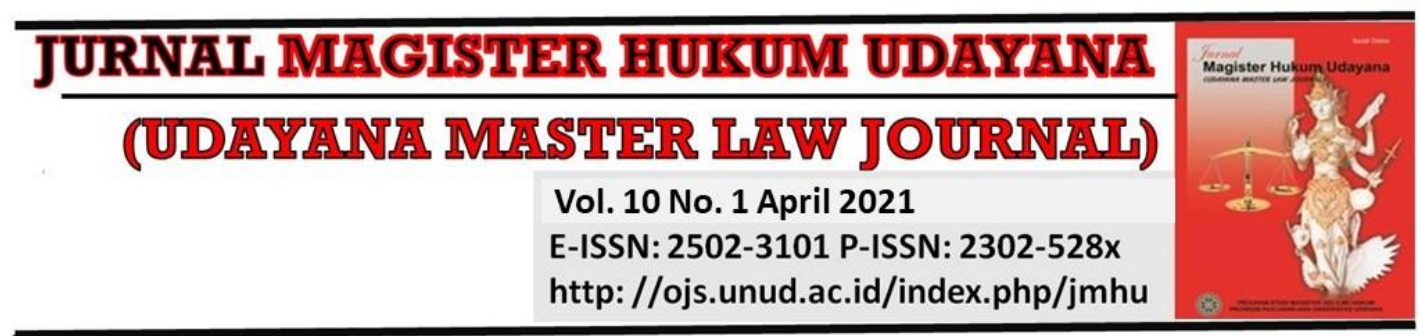

\title{
Jaminan Hak Asasi Manusia dalam Peristiwa Manak Salah di Bali
}

\author{
I Putu Endra Wijaya Negara1, A.A Gede Oka Parwata²
}

${ }^{12}$ Fakultas Hukum Universitas Udayana, E-mail: endrawijaya0505@gmail.com

${ }^{2}$ Fakultas Hukum Universitas Udayana, E-mail: agungokaparwata@gmail.com

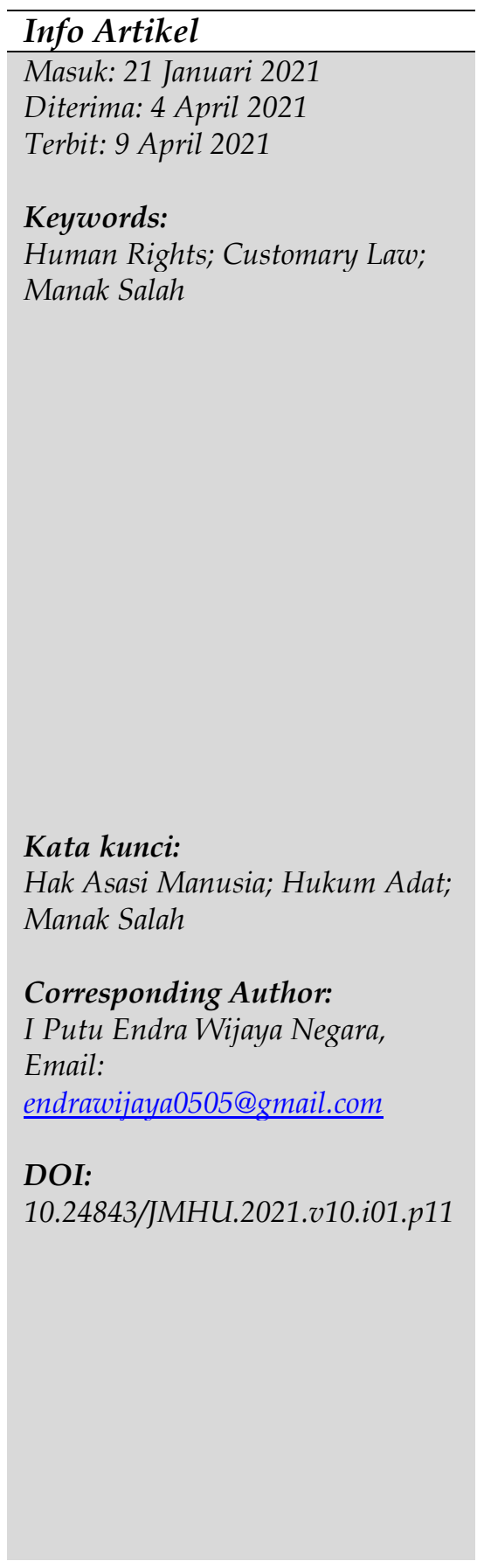

\begin{abstract}
This study aims to determine the arrangement of customary traditions based on Indonesian law and to understand the guarantee of Human Rights in the Manak Salah Tradition in Bali. The method used in research related to human rights assurance in the Manak Salah Tradition in Bali uses normative juridical legal research, using a statutory approach or a statute approach to analyze legal issues in this study. Sources of legal materials in this study consist of primary, secondary, and tertiary legal materials. The results of this study found that human rights guarantee in the Manak Salah Tradition in Bali basically have to be uniform. This is because a tradition will be very difficult to erase, this is because customary law is recognized in the 1945 Constitution of the Republic of Indonesia Article 18B paragraph (2) even though customary law cannot conflict with national law. So that in order to guarantee human rights from the wrong tradition, special arrangements are needed in the form of proper housing facilities, visited by other village krama, provision of MCK facilities, assisted with readiness by all village manners as a whole so as to help ease the burden on the family who is subject to sanctions, help ease the family.
\end{abstract}

\begin{tabular}{l} 
Abstrak \\
\hline Penelitian ini bertujuan untuk mengetahui pengaturan tradisi \\
adat berdasarkan Hukum Indonesia serta memahami jaminan \\
Hak Asasi Manusia (HAM) dalam Tradisi Manak Salah di Bali. \\
Metode yang digunakan dalam penelitian terkait jaminan HAM \\
dalam Tradisi Manak Salah di Bali ini mempergunakan jenis \\
penelitian hukum yuridis normatif, dengan menggunakan \\
pendekatan perundang-undangan atau statute approach dan \\
pendekatan konseptual atau conceptual approach untuk \\
menganalisis isu hukum dalam penelitian ini. Hasil dari studi ini \\
menemukan jika jaminan HAM dalam Tradisi Manak Salah di \\
Bali pada dasarnya harus dilakukan penyeragaman. Hal ini \\
dikarenakan suatu tradisi akan sangat sulit untuk dihapuskan, \\
hal ini dikarenakan hukum adat diakui dalam UUD NRI 1945 \\
Pasal 18B ayat (2) meskipun hukum adat tidak boleh \\
berlawanan dengan hukum positif Indonesia. Sehingga untuk \\
menjamin HAM dari tradisi manak salah diperlukan pengaturan \\
secara khusus berupa fasilitas perumahan yang layak, dikunjungi \\
oleh krama desa yang lain, penyediaan fasilitas MCK, dibantu \\
kesiapannya oleh seluruh krama desa secara keseluruhan \\
sehingga membantu meringankan beban pihak keluarga yang
\end{tabular}


terkena sanksi, membantu meringankan keluarga.

\section{Pendahuluan}

Kebijakan Hak Asasi Manusia (HAM) dalam Undang-Undang Dasar Negara Republik Indonesia Tahun 1945 atau disingkat UUD NRI 1945 yang menjadikan hukum dasar paling tinggi yang wajib di taati oleh negara. Ketentuan-ketentuan tentang HAM karena letaknya ada pada konstitusi maka ketentuan tersebut wajib dihormati serta diberikan jaminan pelaksanaannya oleh negara. Pasal 28I ayat (4) UUD NRI 1945 menjelaskan jika proses dimajukannya, perlindungan, proses ditegakkannya, dan proses dipenuhinya HAM yakni pertanggungjawaban negara utamanya pemerintah. Dalam UUD NRI 1945 aturan yang mengatur mengenai HAM masihlah terbatas, akan tetapi hal tersebut tidak menjadi penghambat terhadap penegakan HAM, karena telah dilengkapi dengan peraturan perundang-undangan lain, meliputi UU No. 48/2009 tentang Kekuasaan Kehakiman, KUHAP, UU No. 39/1999 tentang Hak Asasi Manusia, serta UU No. 26/2000 tentang Pengadilan HAM. Salah satu contoh pengaturan HAM pada UUD NRI 1945 yakni pada Pasal 28 ayat (2) jika hak anak untuk keberlangsungan hidup, tumbuh, serta berkembang dan hak atas dilindunginya dari kekerasan serta diskriminasi. Hal tersebut menunjukkan bahwa kelangsungan masa depan anak menjadi bagian dari penjaminan HAM bagi seluruh Warga Negara Indonesia tanpa terkecuali.

Indonesia merupakan negara yang memiliki beragam khasanah adat dan tradisi melingkupi tatanan kehidupan masyarakatnya yang mengikat seluruh komponen masyarakat pada sebuah ikatan primodial yang kental dan membudaya sehingga pelaksanaannya secara turn-temurun sampai saat ini dijumpai keberadaannya. ${ }^{1}$ Proses berlangsungnya sejarah hukum di Indonesia memberikan catatan jika ahli-ahli hukum yang malah melakukan pembelajaran hukum adat sebagai hukum yang dihidup dimasyarakat Indonesia. ${ }^{2}$ Contohnya Van Vollenhoven, beliau menyebutkan jika seseorang ingin mendapat ilmu serta keterangan mengenai hukum yang hidup di bumi ini, justru dikarenakan keberagaman bentuk pada jaman dulu hingga saat ini, untuk itu seluruh kebijakan Hindia adalah suatu sumber yang tidak kunjung kering untuk dilakukan pembelajaran. ${ }^{3} \mathrm{Hal}$ tersebut berisikan proses diakuinya di lingkungan adat suatu pluralisme hukum adalah hal yang menyenangkan serta karakteristik sesuai Indonesia. ${ }^{4}$

Pada dasarnya, manusia sudah dianugrahi suatu naluri agar bisa memahami bagaimana munculnya gejala-gejala pada kehidupan bermasyarakat.masyara Keinginan tersebut bisa memiliki wujud sebagai keinginan dalam memahami secara

1 I Nyoman Pursika and I Ketut Sudiatmaka, "KEBERTAHANAN TRADISI MANAK SALAH PADA MASYARAKAT PADANG BULIA," in Seminar Nasional Riset Inovatif, vol. 4, 2016.

2 Teddy Anggoro, "KAJIAN HUKUM MASYARAKAT HUKUM ADAT DAN HAM DALAM LINGKUP NEGARA KESATUAN REPUBLIK INDONESIA," Jurnal Hukum \& Pembangunan 36, no. 4 (2017): 487-98.

3 Syamsudin Syamsudin, "Beban Masyarakat Adat Menghadapi Hukum Negara," Jurnal Hukum Ius Quia Iustum 15, no. 3 (2008): 338-51.

${ }^{4}$ Lastuti Abubakar, "Revitalisasi Hukum Adat Sebagai Sumber Hukum Dalam Membangun Sistem Hukum Indonesia," Jurnal Dinamika Hukum 13, no. 2 (2013): 319-31. 
langsung ataupun tidak langsung apa yang menjadi hal yang mengatur tindakan ataupun sikap sehari-hari manusia tersebut. Namun, manusia seringkali tidak memahami jika di dalam hidup sehari-hari tindakannyanya dilakukan pengaturan pada suatu bentuk tertentu, dikarenakan sedari lahir, manusia sudah ada di suatu suatu pola tertentu melalui proses peniruan dan juga memiliki asal dari pendidikan yang sudah didapatkan. ${ }^{5}$ Tata pelaksanaan yang abadi dan kuat integrasinya dengan pola tindakan masyarakat bisa menjadi peningkatan kekuatan mengikat sehingga jadilah adat istiadat. Dalam suatu adat istiadat itu ada beragam kebijakan lisan, dan juga hukum adat. ${ }^{6}$ Kebiasaan ataupun custom adalah ungkapan yang sering digunakan pada kehidupan masyarakat. Masyarakat Bali mempunyai nilai religious yang tinggi, implementasi dari nilai religiusnya yang tinggi dapat dilihat pada pelaksanaan berbagai upacara ritual di sepanjang hidup masyarakatnya, dan bahkan hampir di setiap sisi kehidupan masyarakat Bali tidak akan terlewatkan tanpa melalui sebuah upacara. ${ }^{7}$

Kajeng menyatakan bahwa kelahiran menjadi manusia saat ini merupakan kesempatan melaksanakan kerja baik atau juga kerja buruk, yang hasilnya akan dirasakan di akhirat. Dalam kepencayaan masyarakat Bali setiap proses kelahiran seorang manusia harus melalui sebuah ritual, upacara ritual sepanjang perjalanan hidup manusia pada masyarakat Bali lebih dikenal dengan istilah upacara daur hidup. ${ }^{8}$ Upacara sepanjang hidup manusia disebut dengan life cycle (upacara daur kehidupan). Dalam masyarakat Bali upacara daur hidup ini terdiri dari beberapa tahapan, dimulai sejak dalam kandungan, kelahiran, hingga kematian. ${ }^{9}$

Salah satu wujudnya budaya suatu tradisi yang masih sampai saat ini diberlakukan di Bali adalah tradisi Manak Salah. Manak salah merupakan sebuah kelahiran manusia, yang mana apabila terdapat sebuah keluarga yang melahirkan anak kembar yang berbeda jenis kelamin (perempuan dan laki-laki) di Bali sering disebut dengan istilah kembar buncing. ${ }^{10}$ Masyarakat menganggap bahwa kelahiran kembar buncing telah menyalahi aturan agama dan mengotori keluarga tersebut. Untuk menghindari hal-hal yang buruk maka keluarga yang memiliki kelahiran manak salah harus melaksanakan ritual manak salah. ${ }^{11}$ Tujuan dilaksanakannya ritual manak salah adalah untuk membersihkan secara sekala dan niskala baik bayi kembar buncing, keluarga dan masyarakat yang ada di desa tersebut. ${ }^{12}$

${ }^{5}$ Laurensius Arliman, "Hukum Adat Di Indonesia Dalam Pandangan Para Ahli Dan Konsep Pemberlakuannya Di Indonesia," Jurnal Selat 5, no. 2 (2018): 177-90.

${ }^{6}$ Jimly Asshiddiqie, Pokok-Pokok Hukum Tata Negara Indonesia Pasca Reformasi (Bhuana Ilmu Populer, 2007).

${ }^{7}$ I Gusti Agung Ayu Cintia Dewi, "Manak Salah Dalam Tradisi Lokal Di Desa Pakraman Julah Kabupaten Buleleng," Kamaya: Jurnal Ilmu Agama 1, no. 1 (2018): 49-68.

8 Ibid.

${ }^{9}$ Ibid.

10 "Sekeluarga Jalani Tradisi Manak Salah Setelah Lahir Bayi Kembar Buncing - Koran Buleleng," accessed April 3, 2021, https://koranbuleleng.com/2019/03/15/sekeluarga-jalanitradisi-manak-salah-setelah-lahir-bayi-kembar-buncing/.

11 "Budaya 'Manak Salah' Yang Harus Diubah Di Bali," accessed April 3, 2021, https://www.rancah.com/berita-opini/103060/budaya-manak-salah-yang-harus-diubah-dibali/.

12 Ibid. 
Mengkaji tradisi Manak Salah tidak jarang berbagai pihak dihadapkan pada situasi yang dilema, di satu sisi tradisi Manak Salah sebagai sebuah bentuk kearifan lokal Bali wajib tetap dipertahankan oleh masyarakat setempat dikarenakan memiliki hubungan dengan transformasi budaya dan juga ikatan primodial yang wajib tetap dilakukan dikarenakan memberika pencerminan kepatuhan pada ikatan tradisi pewarisan leluhur yang penuh akan muatan religius magis. Namun, di sisi yang lain, permasalahan muncul saat ditinjau jika ada perlakuan diskriminasi dari pelaksanaan tradisi Manak Salah. Yang mana anak kembar buncing (laki-laki serta perempuan) dinilai sebuah kelahiran yang salah, sehingga jika terdapat kelahiran Manak Salah, desa dalam kondisi cuntaka serta perlu banten atau upacara pembersihan (prengruwatan). Demikian juga kepada pihak keluarga yang memiliki anak kembar buncing (Manak Salah) diasingkan ke kuburan (setra). ${ }^{13}$ Berbicara mengenai tradisi adat Bali tidak akan selesai. Meskipun lembaga adat berulang-ulang berganti nama, tradisi adat tetap saja ada yang menyebabkan permasalahan, baik permasalahan perorangan hingga permasalahan lintas desa adat. Majelis Pembina Lembaga Adat bisa saja berubah tampilan menjadi Majelis Desa Adat atau yang disingkat MDA, namun awigawig tidak seluruhnya dapat dilakukan pengontrolan.

Berdasarkan uraian diatas, maka didalam penelitian ini dapat dirumuskan 2 buah permasalahan, yaitu : (1) Bagaimanakah pengaturan hukum tentang peristiwa manak salah di bali berdasarkan Hukum Indonesia? (2) Bagaimanakah jaminan Hak Asasi Manusia dalam Peristiwa Manak Salah di Bali?

Penelitian ini adalah karya ilmiah asli yang memiliki harapan untuk bisa memberikan kontribusi dan memiliki peran pada proses ditambahkannya ataupun dikembangkannya ilmu pengetahuan. Beberapa studi sejak dulu yang telah melakukan pengkajian tentang tradisi Manak Salah diantaranya pertama, ditemukan pada Jurnal Kertha Widya berjudul Faktor-Faktor yang Mempengaruhi Penerapan Sanksi Adat di Desa Pakraman Penarukan, Kecamatan Buleleng, Kabupaten Buleleng. Kedua, ditemukan Padjajaran Journal of Law yang berjudul The Balinese Traditional Law Instrument: a Realism between the Balance of Cosmic and Human Rights Context. Ketiga yaitu Jurnal Pariksa yang berjudul Implementasi Hukum Adat dengan Sanksi Kasepekang Ditinjau dari Perspektif Hak Asasi Manusia.

Adapun penelitian ini memiliki tujuan yakni Sebagai berikut : (1) Untuk mengetahui pengaturan adat dan tradisi berdasarkan Hukum Indonesia serta (2) Untuk memahami jaminan Hak Asasi Manusia dalam Tradisi Manak Salah di Bali.

\section{Metode Penelitian}

Metode yuridis normatif adalah jenis penelitian dalam studi ini. Kajian mempergunakan metode ini adalah cara penelitian yang dilaksanakan melalui penelitian bahan bahan sekunder atau bahan pustaka. ${ }^{14}$ Dalam penelitian ini menganalisis tentang Jaminan Hak Asasi Manusia dalam Tradisi Manak Salah di Bali. Suatu penelitian hukum yuridis normatif dapat pula dikatakan sebagai suatu prosedur

13 Pursika and Sudiatmaka, "KEBERTAHANAN TRADISI MANAK SALAH PADA MASYARAKAT PADANG BULIA."

${ }^{14}$ Amirudin and Zainal Asikin, Pengantar Metode Penelitian Hukum (Jakarta: Raja Grafindo Persada, 2004). 
penelitian yang menggunakan logika ilmu hukum dari sudut pandang normatif untuk menemukan kebenaran, hal tersebut kemudian mampu menjelaskan Jaminan Hak Asasi Manusia dalam Tradisi Manak Salah di Bali. ${ }^{15}$ Penelitian ini mempergunakan Statute Approach (Pendekatan peraturan Perundang-Undangan) dan Conceptual Approach (Pendektana Konsep) untuk mengkaji permasalahan pada penelitian ini. Penelitian isu hukum ini menggunakan sumber bahan hukum berupa bahan hukum primer, sekunder, dan juga tersier. Sifat dari penelitian ini deskriptif analisis yakni memberikan gambar pada masalah yang dibahas penelitian ini dan melaksanakan analisis terhadap peraturan hukum yang berkaitan agar memberikan jawab atas masalah yang dilakukan perumusan.

\section{Hasil dan Pembahasan}

\subsection{Pengaturan Hukum tentang Peristiwa Manak Salah di Bali}

Adat selain bisa digariskan berdasar keragaman sebagaimana yang ada pada lingkungan hukum (rechtskring), juga bisa dilihat dari sisi yang berbeda, yaitu dari bidang pengkajian, yakni hukum adat tentang tata penyusunan warga (hukum tata negara), adat tentang hubungan antar warga (hukum perdata), adat tentang delik (hukum pidana). Berdasar itu serta untuk melakukan pengkajian adat yang masih layak, dipergunakan sebagai sumber proses dibentuknya hukum nasional. ${ }^{16}$

Pathurohman menyebutkan jika sebagai negara hukum masyarakat Indonesia sudah mempunyai hukum sendiri, yakni hukum yang berasal dari jiwa masyarakat (volkgeist) Indonesia yang dikenal sebagai Hukum Adat. ${ }^{17}$ Surpha juga turut menyebutkan jika hukum adat yakni hukum Indonesia asli yang bentuknya tidak tertulis pada bentuk aturan Indonesia yang berisikan unsur agama. ${ }^{18}$

Kebijakan adat istiadat ini, pada dasarnyanya telah ada pada jaman kuno, jaman PraHindu. Hidupnya adat istiadat pada masyarakat Pra-hindu itu menurut ahli-ahli hukum adat yaitu adat-adat Melayu Polinesia. ${ }^{19}$ Selanjutnya datang budaya Hindu, budaya Islam serta budaya Kristen yang seluruhnya memberikan pengaruh pada budaya asli itu yang sejak lama memberikan penguasaan terhadap tata prikehidupan masyarakat Indonesia sebagai suatu hukum adat. Hal itu menyebabkan hukum adat yang saat ini hidup pada rakyat itu merupakan hasil penggabungan antar kebijakankebijakan adat istiadat jaman Pra-Hindu dengan kebijakan-kebijakan hidup yang dibawa oleh budaya Hindu, budaya Islam serta budaya Kristen. ${ }^{20}$

${ }^{15}$ J Ibrahim, Teori Dan Metodologi Penelitian Hukum Normatif (Malang: Bayu Media, 2011).

${ }^{16}$ Abubakar, "Revitalisasi Hukum Adat Sebagai Sumber Hukum Dalam Membangun Sistem Hukum Indonesia."

17 Fathurokhman Ferry, Evolusi Pemikiran Hukum Baru: Dari Kera Ke Manusia, Dari Positivistik Ke Hukum Progresif (Yogyakarta: Genta Press, 2009).

18 Ibid.

${ }^{19}$ Jawahir Thontowi, "Perlindungan Dan Pengakuan Masyarakat Adat Dan Tantangannya Dalam Hukum Indonesia," Jurnal Hukum Ius Quia Iustum 20, no. 1 (2013): 21-36.

20 Arliman, "Hukum Adat Di Indonesia Dalam Pandangan Para Ahli Dan Konsep Pemberlakuannya Di Indonesia." 
Keberadaan masyarakat adat di Indonesia diberikan pengakuan berdasar konstitusi sebagaimana dilakukan pengaturannya pada UUD NRI 1945 Pasal 18B ayat (2) yakni Negara memberikan pengakuan serta memberikan penghormatan terhadap setiap kesatuan-kesatuan masyarakat adat dan hak-hak tradisional sepanjang masih ada di dunia serta sesuai dengan proses berkembangnya masyarakat serta prinsip NKRI yang dilakukan pengaturannya pada undang-undang. ${ }^{21}$ Pada tatanan praktis contohnya UUD NRI 1945 yang mengintroduksikan Hak Menguasai Negara, dilakukan pengangkatan dari Hak Ulayat, Hak Pertuanan yang secara tradisional diberikan pengakuannya pada hukum adat. Selain diberikan perlindungan oleh konstitusi, eksistensi masyarakat adat pula diberikan perlindungan berdasar UU No.39/1999 tentang HAM sebagaimana dilakukan pengaturannya pada Pasal 6 ayat (1) serta ayat (2) yang mengatur jika dalam rangka proses ditegakkannya HAM perbedaan serta keperluan, dalam masyarakat hukum adat wajib diberikan perhatian serta diberikan perlindungan oleh hukum, masyarakat, maupun pemerintah. Identitas budaya masyarakat hukum adat juga pada hak atas tanah ulayat diberikan perlindungan, harmonis dengan perkembangan jaman. ${ }^{22}$ Masyarakat adat mempunyai pola yang sama untuk melaksanakan penyelesaian permasalahan di masyarakat, yaitu melakukan pengontrolan kehidupan pada masyarakat serta menerapkan sanksi apabila dilakukan pelanggaran yang menyebabkan pemulihan menjadi sangatlah efektif. ${ }^{23}$

Kewenangan hukum adat pula tercantum pada UU No. 48/2009 tentang Kekuasaan Kehakiman. Pasal 5 ayat (1) UU Kekuasaan Kehakiman menyebutkan jika hakim serta hakim konstitusi harus melakukan penggalian, mengikuti serta memberikan pemahaman mengenai nilai-nilai hukum serta rasa keadilan yang hidup pada masyarakat. Proses diakui terdapatnya hukum adat ini bisa dilihat dari kata nilai-nilai hukum serta rasa keadilan yang hidup pada masyarakat. Hal tersebut juga terdapat pada Pasal 50 ayat (1) UU yang sama menyebutkan putusan pengadilan selain wajib berisikan penjelasan serta dasar putusan, juga berisikan pasal tertentu dari hukum positif yang berkaitan ataupun sumber hukum tidak tertulis yang digunakan sebagai landasan dalam mengadili. Kalimat sumber hukum yang tidak tertulis memberikan indikasi proses diakuinya pada nilai hukum adat yang secara general dikatakan hukum yang tidak tertulis. ${ }^{24}$ Penerimaan secara utuh sistem hukum adat pada proses dibentuknya hukum positif di Indonesia pada pelaksanaannya kadang menyebabkan terbenturnya dengan rasa keadilan masyarakat di Indonesia. ${ }^{25}$ Contohnya penerapan tradisi manak salah di Bali, beberapa daerah yang masih menerapkan tradisi ini adalah Desa Julah dan Desa Padang Bulia di Kabupaten Buleleng.

${ }^{21}$ Lalu Sabardi, “Konstruksi Makna Yuridis Masyarakat Hukum Adat Dalam Pasal 18B UUDN RI Tahun 1945 Untuk Identifikasi Adanya Masyarakat Hukum Adat," Jurnal Hukum \& Pembangunan 44, no. 2 (2014): 170-96.

22 Zayanti Mandasari, "Politik Hukum Pengaturan Masyarakat Hukum Adat (Studi Putusan Mahkamah Konstitusi)," Jurnal Hukum Ius Quia Iustum 21, no. 2 (2014): 227-50.

${ }^{23}$ Desi Tamarasari, "Pendekatan Hukum Adat Dalam Menyelesaikan Konflik Masyarakat Pada Daerah Otonom," Indonesian Journal of Criminology 2, no. 1 (2002): 4219.

${ }^{24} \mathrm{H}$ Mustaghfirin, "Sistem Hukum Barat, Sistem Hukum Adat, Dan Sistem Hukum Islam, Menuju Sebagai Sistem Hukum Nasional Sebuah Ide Yang Harmoni," Jurnal Dinamika Hukum 11 (2011): 89-95.

${ }^{25}$ Abubakar, "Revitalisasi Hukum Adat Sebagai Sumber Hukum Dalam Membangun Sistem Hukum Indonesia." 
Istilah manak salah di Desa Julah telah ada sejak abad ke-12 dimana saat itu Bali diperintah oleh Raja Masula-Masuli. Manak salah merupakan sebutan bagi orang yang melahirkan anak kembar laki dan perempuan. Manak salah adalah kelahiran yang disebut tidak wajar, hal ini dikarenakan tidak terdapat manusia yang melahirkan anak langsung dua, ditambah lagi dengan jenis kelamin yang berlainan. Anggapan masyarakat pada waktu itu adalah hanya binatang yang bisa melahirkan bayi lebih dari satu dianggap seperti binatang. Kelahiran seperti ini dijadikan anggapan menyebabkan kotor serta malapetaka bagi keluarga ataupun desa tempat tinggal. ${ }^{26}$

Pada jaman abad ke-12 tersebut melahirkan bayi kembar buncing hanya boleh terjadi pada keluarga raja, dan biasanya kelahiran seperti ini dianggap sebagai berkah dari Hyang Bhatara. Sedangkan apabila kelahiran bayi kembar buncing terjadi pada rakyat biasa, maka kelahiran itu dikatakan salah dan dianggap akan mendatangkan bencana. ${ }^{27}$ Raja mengeluarkan pernyataan seperti itu supaya posisi raja tidak bisa disamakan dengan rakyat biasa, maka kelahiran itu dikatakan salah dan dianggap akan mendatangkan bencana. Tujuan dilaksanakannya kebijakan itu yakni untuk melakukan proses dipertahankannya posisi ataupun kewibawaan seorang raja, yang jika hal tersebut dilakukan pembiaran maka masyarakat memebrikan anggapan akan lahirnya pimpinan baru. Dengan demikian raja memberikan perintah agar setiap desa yang melahirkan anak kembar buncing wajib diasinglan di pinggiran desa serta setelah itu dibuat suatu upacara yang disebut dengan upacara manak salah.

\subsection{Jaminan Hak Asasi Manusia dalam Tradisi Manak Salah di Bali}

Desa adat di Bali merupakan sejarah yang telah ada selama bertahun-tahun lalu, saat Mpu Kuturan melakukan perkenalan ikatan warga pakraman yang dikarakteristikkan dengan terdapatnya tiga pura yang disebut Tri Kahyangan. ${ }^{28}$ Berdasar hal tersebutlah timbul penyebutan agama menjadi jiwa dari adat. Jaman Mpu Kuturan itu ikatan desa adat merupakan suatu hal yang mutlak, dikarenakan jumlah desa tidaklah banyak serta jarak desa satu dengan yang lain berjauhan. Sumber pendapatan rakyat pada satu desa pun sama. Namun, saat desa itu semakin banyak, rakyat terus bertambah, sumber pendapatan berlainan, serta pemerintah melaksanakan perkenalan desa dinas, adanya desa adat tidak pernah dilakukan pemikiran lebih serius, utamanya dalam hal apa pengikat tersebut, yaitu awig-awig adat, masih layak atau tidak dengan kondisi jaman. Inilah inti permasalahan, tetapi kita bersyukur, banyaknya awig-awig adat yang sudah diperbaharui yang tidak mengekang masyarakat yang menjadi anggota adat itu.

Menurut I Ketut Wiana dalam jurnal Pasek Pramana dan Niti Suari Giri menjelaskan bahwa, Di dalam ajaran Hindu tidak dikenal kasta. Hindu hanya mengenal varna yang terbagi atas 4 (empat) golongan, yakni Brahmana, Ksatria, Waisya, serta Sudra. Keempat golongan tersebut bukanlah ditentukan berdasarkan keturunan (wangsa), melainkan guna dan karma. Pada intinya, keempat golongan tersebut kedudukan

${ }^{26}$ Dewi, "Manak Salah Dalam Tradisi Lokal Di Desa Pakraman Julah Kabupaten Buleleng."

27 "Ketika Kembar Buncing 'Dibuang', Raja Kaba Kaba Ganti Dengan Upacara," accessed April 3, 2021, https:// baliexpress.jawapos.com/read/2020/02/12/179063/ketika-kembar-buncingdibuang-raja-kaba-kaba-ganti-dengan-upacara.

28 Putu Maria Ratih Anggraini and I Wayan Titra Gunawijaya, "HUKUM ADAT KEKELUARGAAN DAN KEWARISAN DI BALI," Pariksa 2, no. 1 (2020). 
sosialnya sejajar namun pencahariannya yang berbeda-beda. Sehingga terdapat kesalah pahaman dalam pelaksanaan ajaran varna, dengan demikian varna dapat diartikan sama dengan wangsa dan/atau dalam bahasa modernnya yang pada saat ini disebut dengan istilah kasta ${ }^{29}$. Dalam kaitannya dengan manak salah, bayi kembar buncing yang lahir di lingkungan kerajaan yakni dipercaya mendatangkan kebahagiaan dan karunia. Akan tetapi, bayi kembar buncing dikatakan sebagai manak salah apabila lahir dari krama desa adat jaba wangsa yang dipercayai akan membawa suatu malapetaka. Sehingga berakibat hanya pada mereka yang berkasta diberikan ruang untuk memiliki kesempatan untuk melahirkan anak dalam kondisi manak salah, dengan demikian tentu penjatuhan sanksi adat terhadap peristiwa manak salah sudah sepatutnya dihapus, karena hukum adat dapat berubah berdasrkan waktu dan tempat dalam setiap perkembangan masyarakat hukum akan selalu beradaptasi sesuai dengan perkembangan zaman yang terjadi sampai saat ini. Hukum adat juga dikatakan mempunyai sifat yang terbuka, dimana hukum adat menerima suatu sistem hukum yang lain sepanjang masyarakat yang berhubungan menganggap bahwa sistem hukum lain di Indonesia bersebut layak dan sesuai. Dengan demikian dalam penjatuhan sanksi adat terhadap peristiwa manak salah sepatutnya tidak dipertahankan, karena bertentangan dengan HAM.

Hal-hal yang signifikan serta layak mengenai perihal tersebut merupakan desa adat, pemerintah serta pihak yang memperhatikan HAM. Pada hal ini pihak desa pakraman seharusnya melakukan pengkajian dengan lebih cermat mengenai awig-awig desa (kebijakan desa) yang dilakukan penyusunan sehingga tidak berbenturan dengan hukum yang berlaku. Bendesa Adat wajib menjadi pemberi inisiatif dan juga pemberi fasilitas untuk melakukan pengelolaan krama desa adat dalam melaksanakan pemahaman konsep manak salah dilakukan pengaitan dengan HAM. Selanjutnya, bendesa pakraman diberikan dukungan oleh pengurus desa adat lainnya, haruslah saling membantu dalam menyeragamkan langkah serta mempersatukan persepsi pada konsep manak salah. Bahwa penghakiman kesalahan pada seorang yang melahirkan anak kembar buncing merupakan tidak benar. Dengan demikian awig-awig yang akan dilaksanakan di wilayah desa pakraman seharusnya dilakukan perbandingan dengan aturan positif yang berlaku. Selanjutnya yang perlu diberikan perhatian yakni awigawig tersebut tidak menciptakan pelanggaran HAM.

HAM merupakan salah satu konsep yang dianut oleh negara Indonesia yang dilandasi Pancasila. HAM di Indonesia menekankan pada keluhuran martabat manusia secara menyeluruh. Konsep HAM sebagai proses dijabarkannya Pancasila sudah dicantumkan pada pembukaan UUD NRI 1945 serta pada beberapa pasalnya. HAM sebagai proses dijabarkannya Pancasila, tidak hanya berkaitan tentang kebebasan namun juga keadilan. ${ }^{30}$ Pemerintah baik pusat ataupun daerah sebagai pihak yang mengayomi kehidupan bangsa dan masyarakat, seharusnya memberikan perhatian pada kearifan lokal yang ada di masyarakat. Proses dicermatinya dilaksanakan dalam kerangka melaksanakan sinergi serta melakukan penyelarasan kearifan lokal, dengan

${ }^{29}$ I Gede Pasek Pramana and Ni Putu Niti Suari Giri, "PENGANGKATAN ANAK BEDA KASTA DALAM PERSPEKTIF HUKUM DAN HAK ASASI MANUSIA," Jurnal Hukum Saraswati (JHS) 2, no. 1 (2020): 80-97.

${ }^{30}$ Gede Yoga Satriya Wibawa and I Gede Arya Wiradnyana, "Implementasi Hukum Adat Dengan Sanksi Kasepekang Ditinjau Dari Perspektif Hak Asasi Manusia," Pariksa 1, no. 1 (2020). 
demikian tidak berlawanan dengan hukum positif yang berlaku. Pada tradisi manak salah, untuk itu pemerintah harus melaksanakan pemetaan pada daerah yang dianggap menerapkan konsep itu. Pemerintah bisa melaksanakan pemahaman mengenai segala kebijakan yang ada, hal-hal yang berkaitan dengan hidup masyarakat dan negara termasuk juga HAM. Dengan demikian, pelaksana terkait seharusnya melaksanakan pendekatan yang lebih mengajak sehingga tidak terjadinya rasa iri dan tersinggung dalam masyarakat. Hal ini dikarenakan masyarakat melaksanakan penerimaan konsep itu secara berkelanjutan, hal ini menjadi kepercayaan yang sangat kuat. Untuk itu usaha penyadaran pada masyarakat seharusnya dilaksanakan secara bertahap serta berkesinambungan kemudian setiap pergantian bisa dimengerti dengan baik.

Kebijakan itu perlu dilakukan penyesuaian dengan keadaan jaman sekarang, sesuai dengan sistem fleksibel dan dinamis, apabila mengacu pada sistem hukum adat, karena biarpun hukum kerajaan dan hukum adat itu berbeda tetapi cakupannya tentang kebiasaan masyarakat meresepsikan sebuah aturan, hukum kerjaan dan hukum adat, ada sebuah korelasi sesuai dengan historis lahirnya hukum adat yang lahir dari kebiasaan yang mengakibatkan sebuah hukum. Jadi, pengaturan tentang Hak Asasi Manusia pada keberlakuan tradisi manak salah perlu ditinjau kembali keberadaannya yang memiliki tujuan:

1. Memberikan perwujudan kebebasan yang dapat dipertanggungjawabkan sebagai bentuk implementasi HAM sesuai berdasar Pancasila serta UUD 1945.

2. Memberikan perwujudan proses dilindunginya hukum yang konsisten serta berkelanjutan untuk memberikan jaminan kemerdekaan proses penyampaian aspirasi.

3. Memberikan perwujudan iklim yang kondusif bagi proses perkembangan kontribusi serta kreativitas setiap warga negara sebagai suatu wujud hak maupun pertanggungjawaban pada hidup berdemokrasi.

4. Memberikan tempat pertanggungjawaban sosial pada kehidupan bermasyarakat, berbangsa serta bernegara dengan tidak melakukan pengabaian keperluan perorangan ataupun kelompok.

Instrumen hukum adat wajib selalu selaras dengan hukum positif Indonesia serta hukum internasional, utamanya yang berkaitan dengan nilai-nilai HAM. Walaupun sifatnya memiliki tujuan melakukan penjagaan seimbangnya kosmik ataupun alam, instrumen baik hukum internasional maupun nasional mengenai HAM butuh dipergunakan sebagai bahan oleh Desa Pakraman untuk melakukan pembangunan kebijakan-kebijakan adat. ${ }^{31}$

Secara konsep, kontruksi berpikir saat melaksanakan penafsiran pada hukum adat Bali wajiblah dibentuk didasari atas wiweka (pengetahuan dan penalaran logis) tidak atas dasar sentimenisme, egosentrisme, maupun fanatisme. Melihat kondisi tersebut maka haruslah di lakukan pengaturan secara khusus terkait tradisi manak salah ini, yang selanjutnya akan dilaksanakan secara seragam oleh desa adat yang masih menerapkan tradisi manak salah. Hal ini dikarenakan di satu sisi agar tetap menjaga kebertahanan tradisi manak salah karena sangat sulit menghapus hal tersebut dengan keberadaan

${ }^{31}$ I Gede Yusa and Ni Ketut Supasti Dharmawan, “The Balinese Traditional Law Instrument: A Realism between the Balance of Cosmic and Human Rights Context," PADJADJARAN Jurnal Ilmu Hukum (Journal of Law) 5, no. 3 (2019), https:// doi.org/10.22304/ pjih.v5n3.a3. 
masyarakat Bali karena ikatan niskala turun-temurun dari masyarakat setempat. Di sisi yang lain kebertahanan tradisi haruslah memperhatikan jaminan perlindungan HAM berupa prosedur pengenaan sanksi dan perlakuan adat terhadap pihak keluarga yang mempunyai anak kembar buncing. Pengaturan yang dimaksud yaitu pengaturan berupa :

1. Kedua orang tua beserta bayinya disediakan fasilitas perumahan yang layak serta memenuhi standar layak huni dengan difasilitasi tenaga medis mendampingi proses pengasingan, warga masyarakat atau karma desa secara bergiliran mengunjungi pihak keluarga yang terkena sanksi kesepekang sebagai sikap kepedulian terhadap sesame (menyama braya), walaupun pindah ke rumah darurat sementara Aparatur Desa Adat tetap secara intensif dan bergiliran melakukan kunjungan tentang kondisi pihak keluarga yang terkena sanksi kesepekang tersebut.

2. Selama ada pada wilayah di ungsikan, kedua orang tua sang bayi dan bayi tersebut tidak diijinkan keluar dari desa, tetapi justru dikunjungi oleh krama desa yang lain.

3. Penyediaan fasilitas MCK yang memadai dan layak sesuai standar hygiene and sanitation.

4. Satu hari menuju selesainya masa mengungsi ini sang orang tua diharuskan melaksanakan upacara adat lain yaitu upacara pecaruan di Jaba Pura Desa, yang dibantu kesiapannya oleh seluruh krama desa secara keseluruhan sehingga membantu meringankan beban pihak keluarga yang terkena sanksi tadi.

5. Demikian juga halnya dengan sehari selanjutnyanya sang orang tua bayi kembar buncing ini diwajibkan juga melaksanakan upacara melasti ke laut yang dipercaya sebagai peluruhan segala kesialan. Namun karena bantuan krama desa dalam persiapan upacara sangat membantu meringankan keluarga si bayi dari segi pembiayaan.

6. Dan keterlibatan krama desa ikut ambil bagian membantu, dapat dilihat pada ritual penutup dihitung satu hari setelah melaksanakan upacara melasti selama 3 hari orang tua bayi serta bayi tersebut melakukan persembahyangan di tiga Pura Desa yang memiliki Balai Agung Pegat. Setelah selesainya masa persembahyangan di hari ke-3 maka masa diasingkan keluarga ini berakhir serta yang berkaitan dengan hal tersebut diijinkan kembali ke tempat tinggalnya ataupun melaksanakan perjalanan ke luar desa.

Masyarakat Bali yang hidupnya didasari oleh agama Hindu juga mengenal nilai-nilai HAM. Nilai-nilai HAM tersebut dapat dilihat dari ajaran Tat Twam Asi. Ajaran tersebut memberikan pengajaran untuk saling menghormati satu dengan yang lain atau tidak saling menyakiti antar sesama. Selain ajaran tersebut, masih banyak ajaran agama Hindu lainnya yang berisikan nilai-nilai HAM. HAM yang dianut oleh masyarakat Bali dijadikan acuan supaya tidak melakukan tindakan serta menunjukkan sikap melawan HAM dan wajib berupaya melakukan penegakan HAM.

\section{Kesimpulan}

Jaminan HAM dalam Tradisi Manak Salah di Bali pada dasarnya harus dilakukan penyeragaman. Hal ini dikarenakan suatu tradisi akan sangat sulit untuk dihapuskan, hal ini dikarenakan hukum adat diakui dalam UUD NRI 1945 Pasal 18B ayat (2) meskipun hukum adat tidak boleh berlawanan dengan hukum nasional. Sehingga 
untuk menjamin HAM dari tradisi manak salah diperlukan pengaturan secara khusus berupa fasilitas perumahan yang layak, dikunjungi oleh krama desa yang lain, penyediaan fasilitas MCK, dibantu kesiapannya oleh seluruh krama desa secara keseluruhan sehingga membantu meringankan beban pihak keluarga yang terkena sanksi, membantu meringankan keluarga.si bayi dari segi pembiayaan, keterlibatan krama desa ikut ambil bagian membantu dalam penutupan ritual. Di dalam ajaran Hindu tidak dikenal kasta. Hindu hanya mengenal varna yang terbagi atas 4 (empat) golongan, yakni Brahmana, Ksatria, Waisya, serta Sudra. Sehingga berakibat hanya pada mereka yang berkasta diberikan ruang untuk memiliki kesempatan untuk melahirkan anak dalam kondisi manak salah, dengan demikian tentu penjatuhan sanksi adat terhadap peristiwa manak salah sudah sepatutnya dihapus, karena hukum adat dapat berubah berdasrkan waktu dan tempat dalam setiap perkembangan masyarakat hukum akan selalu beradaptasi sesuai dengan perkembangan zaman yang terjadi sampai saat ini. Hukum adat juga dikatakan mempunyai sifat yang terbuka, dimana hukum adat menerima suatu sistem hukum yang lain sepanjang masyarakat yang berhubungan menganggap bahwa sistem hukum lain di Indonesia bersebut layak dan sesuai. Dengan demikian dalam penjatuhan sanksi adat terhadap peristiwa manak salah sepatutnya tidak dipertahankan, karena bertentangan dengan HAM

\section{Daftar Pustaka}

Abubakar, Lastuti. "Revitalisasi Hukum Adat Sebagai Sumber Hukum Dalam Membangun Sistem Hukum Indonesia." Jurnal Dinamika Hukum 13, no. 2 (2013): 319-31.

Amirudin, and Zainal Asikin. Pengantar Metode Penelitian Hukum. Jakarta: Raja Grafindo Persada, 2004.

Anggoro, Teddy. "KAJIAN HUKUM MASYARAKAT HUKUM ADAT DAN HAM DALAM LINGKUP NEGARA KESATUAN REPUBLIK INDONESIA." Jurnal Hukum E Pembangunan 36, no. 4 (2017): 487-98.

Anggraini, Putu Maria Ratih, and I Wayan Titra Gunawijaya. "HUKUM ADAT KEKELUARGAAN DAN KEWARISAN DI BALI." Pariksa 2, no. 1 (2020).

Arliman, Laurensius. "Hukum Adat Di Indonesia Dalam Pandangan Para Ahli Dan Konsep Pemberlakuannya Di Indonesia." Jurnal Selat 5, no. 2 (2018): 177-90.

Asshiddiqie, Jimly. Pokok-Pokok Hukum Tata Negara Indonesia Pasca Reformasi. Bhuana Ilmu Populer, 2007.

“Budaya 'Manak Salah' Yang Harus Diubah Di Bali." Accessed April 3, 2021. https://www.rancah.com/berita-opini/103060/budaya-manak-salah-yangharus-diubah-di-bali/.

Dewi, I Gusti Agung Ayu Cintia. "Manak Salah Dalam Tradisi Lokal Di Desa Pakraman Julah Kabupaten Buleleng." Kamaya: Jurnal Ilmu Agama 1, no. 1 (2018): 49-68.

Ferry, Fathurokhman. Evolusi Pemikiran Hukum Baru: Dari Kera Ke Manusia, Dari Positivistik Ke Hukum Progresif. Yogyakarta: Genta Press, 2009.

Ibrahim, J. Teori Dan Metodologi Penelitian Hukum Normatif. Malang: Bayu Media, 2011.

"Ketika Kembar Buncing 'Dibuang', Raja Kaba Kaba Ganti Dengan Upacara." Accessed April 3, 2021. https://baliexpress.jawapos.com/read/2020/02/12/179063/ketika-kembarbuncing-dibuang-raja-kaba-kaba-ganti-dengan-upacara.

Mandasari, Zayanti. "Politik Hukum Pengaturan Masyarakat Hukum Adat (Studi 
Putusan Mahkamah Konstitusi)." Jurnal Hukum Ius Quia Iustum 21, no. 2 (2014): 227-50.

Mustaghfirin, H. "Sistem Hukum Barat, Sistem Hukum Adat, Dan Sistem Hukum Islam, Menuju Sebagai Sistem Hukum Nasional Sebuah Ide Yang Harmoni." Jurnal Dinamika Hukum 11 (2011): 89-95.

Pramana, I Gede Pasek, and Ni Putu Niti Suari Giri. "PENGANGKATAN ANAK BEDA KASTA DALAM PERSPEKTIF HUKUM DAN HAK ASASI MANUSIA." Jurnal Hukum Saraswati (JHS) 2, no. 1 (2020): 80-97.

Pursika, I Nyoman, and I Ketut Sudiatmaka. "KEBERTAHANAN TRADISI MANAK SALAH PADA MASYARAKAT PADANG BULIA." In Seminar Nasional Riset Inovatif, Vol. 4, 2016.

Sabardi, Lalu. "Konstruksi Makna Yuridis Masyarakat Hukum Adat Dalam Pasal 18B UUDN RI Tahun 1945 Untuk Identifikasi Adanya Masyarakat Hukum Adat." Jurnal Hukum \& Pembangunan 44, no. 2 (2014): 170-96.

"Sekeluarga Jalani Tradisi Manak Salah Setelah Lahir Bayi Kembar Buncing - Koran Buleleng." Accessed April 3, 2021. https:/ / koranbuleleng.com/2019/03/15/sekeluarga-jalani-tradisi-manaksalah-setelah-lahir-bayi-kembar-buncing/.

Syamsudin, Syamsudin. "Beban Masyarakat Adat Menghadapi Hukum Negara." Jurnal Hukum Ius Quia Iustum 15, no. 3 (2008): 338-51.

Tamarasari, Desi. "Pendekatan Hukum Adat Dalam Menyelesaikan Konflik Masyarakat Pada Daerah Otonom." Indonesian Journal of Criminology 2, no. 1 (2002): 4219.

Thontowi, Jawahir. "Perlindungan Dan Pengakuan Masyarakat Adat Dan Tantangannya Dalam Hukum Indonesia." Jurnal Hukum Ius Quia Iustum 20, no. 1 (2013): 21-36.

Wibawa, Gede Yoga Satriya, and I Gede Arya Wiradnyana. "Implementasi Hukum Adat Dengan Sanksi Kasepekang Ditinjau Dari Perspektif Hak Asasi Manusia." Pariksa 1, no. 1 (2020).

Yusa, I Gede, and Ni Ketut Supasti Dharmawan. "The Balinese Traditional Law Instrument: A Realism between the Balance of Cosmic and Human Rights Context." PADJADJARAN Jurnal Ilmu Hukum (Journal of Law) 5, no. 3 (2019). https://doi.org/10.22304/pjih.v5n3.a3.

\section{Peraturan Perundang-Undangan}

Undang-Undang Dasar Negara Republik Indonesia Tahun 1945.

Undang-Undang Republik Indonesia Nomor 39 Tahun 1999 tentang Hak Asasi Manusia (LN No.: 165, TLN No. : 3886).

Undang-Undang Republik Indonesia Nomor 48 Tahun 2009 tentang Kekuasaan Kehakiman (LN No. : 157, TLN No.: 5076). 